\title{
Correction to: Amyloid $\beta$-protein oligomers promote the uptake of tau fibril seeds potentiating intracellular tau aggregation
}

Woo Shik Shin ${ }^{1}$, Jing Di ${ }^{1}$, Qin Cao ${ }^{2}$, Binsen Li ${ }^{1}$, Paul M. Seidler ${ }^{2}$, Kevin A. Murray ${ }^{2}$, Gal Bitan ${ }^{1,3}$ and Lin Jiang ${ }^{1,3^{*}}$

Correction to: Alz Res Therapy 11, 86 (2019) https://doi.org/10.1186/s13195-019-0541-9

Following publication of the original article [1], the authors reported an error in the supplementary Fig. 4. One of the fluorescent cell images from control "No A $\beta$ " experiments was misplaced. The corrected supplementary Fig. 4 is given here as Fig. 1.
The original article can be found online at https://doi.org/10.1186/s13195019-0541-9.

* Correspondence: jianglin@ucla.edu

'Department of Neurology, David Geffen School of Medicine, UCLA, Los Angeles, CA 90095, USA

${ }^{3}$ Brain Research Institute, and Molecular Biology Institute, UCLA, Los Angeles, CA 90095, USA

Full list of author information is available at the end of the article

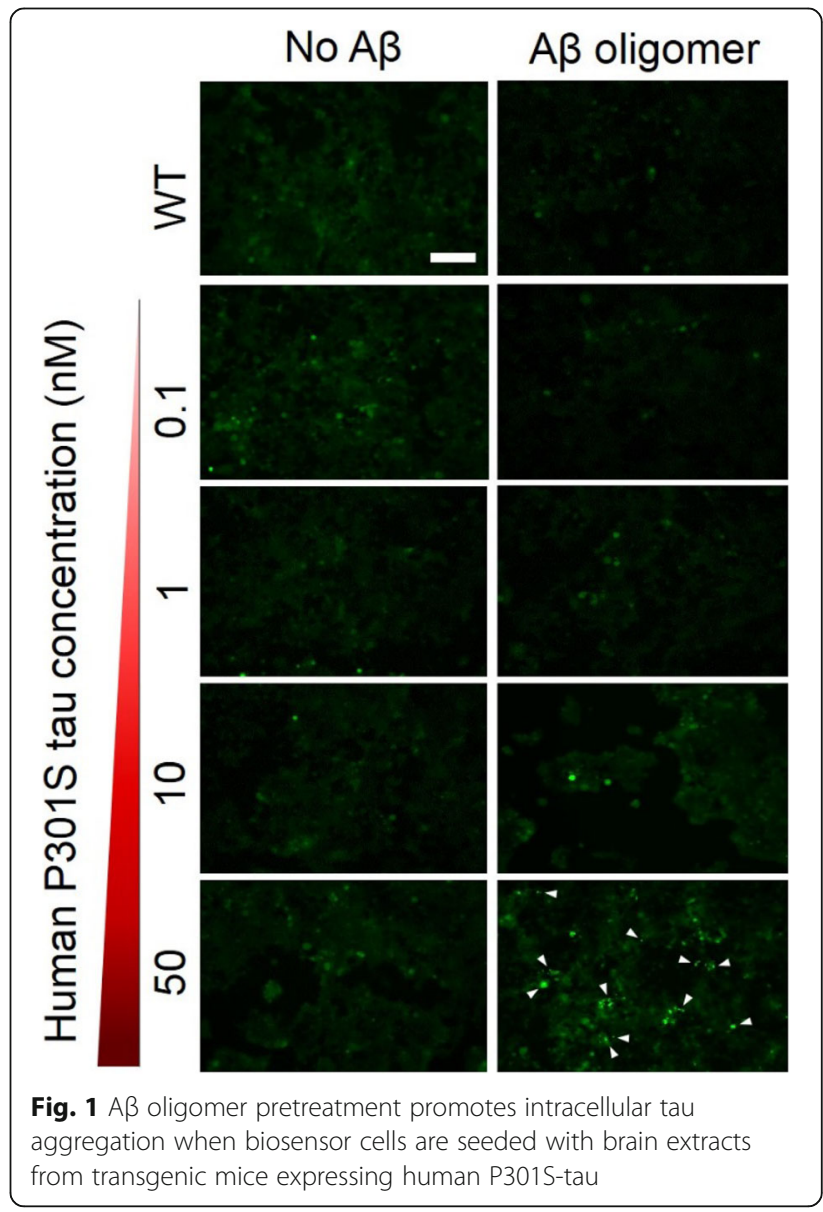

aggregation when biosensor cells are seeded with brain extracts from transgenic mice expressing human P301S-tau

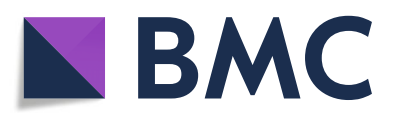

(- The Author(s). 2021 Open Access This article is licensed under a Creative Commons Attribution 4.0 International License, which permits use, sharing, adaptation, distribution and reproduction in any medium or format, as long as you give appropriate credit to the original author(s) and the source, provide a link to the Creative Commons licence, and indicate if changes were made. The images or other third party material in this article are included in the article's Creative Commons licence, unless indicated otherwise in a credit line to the material. If material is not included in the article's Creative Commons licence and your intended use is not permitted by statutory regulation or exceeds the permitted use, you will need to obtain permission directly from the copyright holder. To view a copy of this licence, visit http://creativecommons.org/licenses/by/4.0/. The Creative Commons Public Domain Dedication waiver (http://creativecommons.org/publicdomain/zero/1.0/) applies to the data made available in this article, unless otherwise stated in a credit line to the data. 


\section{Author details}

'Department of Neurology, David Geffen School of Medicine, UCLA, Los

Angeles, CA 90095, USA. ${ }^{2}$ Departments of Chemistry and Biochemistry and Biological Chemistry, UCLA-DOE Institute, UCLA, Los Angeles, CA 90095-1570,

USA. ${ }^{3}$ Brain Research Institute, and Molecular Biology Institute, UCLA, Los

Angeles, CA 90095, USA.

Published online: 19 April 2021

\section{Reference}

1. Shin WS, Di J, Cao Q, et al. Amyloid $\beta$-protein oligomers promote the

uptake of tau fibril seeds potentiating intracellular tau aggregation. Alz Res Therapy. 2019;11:86 https://doi.org/10.1186/s13195-019-0541-9. 